\title{
GENETIC DIVERSITY IN FICUS SYCOMORUS L. SPECIES (MORACEAE) USING RAPD AND IRAP MARKERS
}

\author{
BASEL SALEH
}

Atomic Energy Commission of Syria, Damascus

SALEH, B.: Genetic diversity in Ficus sycomorus L. species (Moraceae) using RAPD and IRAP markers. Agriculture (Pol'nohospodárstvo), vol. 59, 2013, no. 3, pp. 120-130.

\begin{abstract}
This study was conducted in order to assess accuracy, repeatability and reproducibility of the RAPD and IRAP techniques for determining the genetic variability in 10 Ficus sycomorus L. genotypes grown in the coastal regions of Syria. Thirty-six RAPD primers applied gave 352 discernible loci, of which $252(71.59 \%)$ were polymorphic. Polymerase chain reaction (PCR) amplification with 36 RAPD primers gave an average of 9.778 selected markers/primers, with a maximum of 21 (OPA18) and a minimum of five (OPG11, OPK12 and OPT18). The amplification with 22 IRAP primers (single or combination) generated 178 bands, of which 151 (84.83\%) were polymorphic, with an average of 11.125 selected markers/
\end{abstract}

primer, with a maximum of 17 (IRAP-TDK11F) and a minimum of seven (BREP1F+BREP1R, IRAP-TDK1F+IRAP-TDK1R and IRAP-TDK2F+IRAP-TDK2R). In the present investigation, the IRAP marker was more efficient than the RAPD assay, where the latter exhibited a lower marker index (MI) average (1.629) compared with the IRAP technique (2.941). Otherwise, F. sycomor 4 genotype showed the highest dissimilarity compared with other genotypes studied in this investigation. Based upon the estimated percent disagreement values (PDV), we can suggest that there are three subspecies present among the 10 samples tested.

Key words: Ficus sycomorus L.; genotype; IRAP; marker index; polymorphism; RAPD

Ficus sycomorus L. species arranged as a subgenus of the fig, belongs to the Moraceae family. Within the genus Ficus, approximately 400 monoecious and 800 gynodioecious species are in existence (Al Malki \& Elmeer 2010). The name, sycomorus, comes from the Greek syca-morus which means mulberry fig. The trees are not as cold-hardy as the common fig Ficus carica L. They are usually grown in the warmer regions of the Middle East and Africa. F. sycomorus L. is a rare perennial tree or sub-tree. It was originally brought from Ethiopia and Central Africa. It has been planted since antiquity in Egypt, Palestine, Lebanon and Syria. It is presently becoming rare because of urban development. Thus, the rest of this species can be found in Sida and Syrian littoral zones (Mouterde 1966). It is known as Sycmore as a common English name, and as Al-Joumayz as a common Arabic name. This species is becoming one of the endangered species leading to extinction, among other plant genetic resources in Syria.

However, there are some efforts for characterisation and conservation of the genetic diversity to prevent their potential extinction and further utilisation. This species shows a good tolerance for an abiotic stress (salinity) in addition to being traditionally appreciated for its ripe fruits. It plays an important role in traditional treatment of many diseases and ailments. In coastal regions from Syria, the stem bark of Ficus sycomorus L. is traditionally used to treat fungal diseases.

Syria is an important region for different plant genetic resources (wild and cultivated species) in the world because of its diverse ecosystems and cli- 
matic conditions. Syria is considered to be a centre of origin and biodiversity for many crops, feeds and fruit trees (Zohary 1962, 1973). It is one of the few core centres where numerous species of temperate-zone agricultural specimens originated thousands of years ago, and where third-world relatives and land races of enormous genetic diversity are still present. Estimates indicated that Syrian flora includes about 3,150 species arranged in 919 genus and 133 families (Barkoudah et al. 2000).

Different marker systems are currently available for monitoring and assessing genetic diversity. Random amplified polymorphic DNA (RAPD) markers established by Williams et al. (1990) are DNA fragments from PCR amplification of random segments of genomic DNA with a single primer of arbitrary nucleotide sequences, which are able to differentiate between genetically distinct individuals. This technique is simple to use, and does not need any sequence information. The RAPD marker becomes one of the fewer molecular techniques for assessing genetic variation in fig in many countries; for example, in Italy (De-Masi et al. 2005), in Tunisia (Salhi-Hannaci et al. 2006; Baraket et al. 2011), in Egypt (Hadia et al. 2008), in Japan (Ikegami et al. 2009), and also in Turkey (Akbulut et al. 2009; Dalkilic et al. 2011). New techniques based on DNA profiling provide novel approaches to identification of the varieties, which offer advantages over traditional morphological comparisons. Inter-retrotransposon amplified polymorphism (IRAP) displays insertional polymorphisms by amplifying the segments of DNA between two retrotransposons. The IRAP marker detects high levels of polymorphism which does not need DNA digestion, ligations, or probe hybridisation to generate marker data, thus increasing the reliability and robustness of the assay. Mobile genetic elements, retrotransposons, generally show widespread chromosomal dispersion, variable copy number, and random distribution in the genome.

The IRAP marker is one among other retrotransposon-based markers which are a new group of markers applied successfully in genetic variation studies in various plant crops, for example, in banana (Nair et al. 2005), in barley (Alavi-Kia et al. 2008), in Aegilops (Saeidi et al. 2008), in potato
(Novakova et al. 2009) and recently in flax (Linum usitatissimum L.) (Smýkal et al. 2011).

IRAP could be performed as an accurate, repeatable and reproducible marker compared with the RAPD system (Biswas et al. 2009). As yet, our knowledge of the Ficus genus breeding system and its evolution has been shaped by taxonomy, anatomy, ecology, pollinator behaviour and genetic variability. However, phylogenetic studies in $F$. sycomorus L. species have not yet been examined in detail. Therefore, this investigation was performed to assess genetic variation in $F$. sycomorus L. species in Syria using RAPD and IRAP markers. Comparative assessment of PCR-based markers (RAPD and IRAP) was carried out, and their potential application as marker systems was investigated for their utility in phylogenetic relationships within this species.

\section{MATERIAL AND METHODS}

\section{Plant materials}

Ten samples were collected from their natural habitats along the coastal regions of Syria (Table 1). These geographical regions consist of altitudes ranging from $4.5 \mathrm{~m}$ to $250 \mathrm{~m}$ from the wet coastal regions. Sampling was carried out in autumn from trees spread on clay soil, and where annual rainfall ranged from $650 \mathrm{~mm}$ to $850 \mathrm{~mm}$.

\section{Total DNA isolation}

The genomic DNA of the plant was extracted from young leaves of 10 samples of $F$. sycomorus species in Syria (bulk of 5 leaves/tree for each representative genotype) by a CTAB (cetyltrimethylammonium bromide) protocol as described by Doyle and Doyle (1987) with minor modifications. Leaf tissue $(150 \mathrm{mg}$ ) was ground in liquid nitrogen, the powder was transferred to a 2-ml Eppendorf tube, mixed with $900 \mu \mathrm{l}$ of extraction buffer (100 $\mathrm{mM}$ Tris-HCl, $\mathrm{pH}$ 8.0, 1.4 M NaCl, $20 \mathrm{mM}$ EDTA, $0.0018 \mathrm{ml} \beta$-mercaptoethanol, $2 \%$ CTAB), and incubated at $65^{\circ} \mathrm{C}$ for $20 \mathrm{~min}$. DNA was extracted with one volume of a chloroform:isoamyl alcohol mix $(24: 1, \mathrm{v} / \mathrm{v})$, and centrifuged at $12,000 \mathrm{~g}$ for $10 \mathrm{~min}$ at $4{ }^{\circ} \mathrm{C}$. The aqueous phase was transferred to a fresh tube, and the DNA was precipitated with an equal 
volume of cold isopropanol and kept at $-20^{\circ} \mathrm{C}$ for $10 \mathrm{~min}$, then centrifuged at $12,000 \mathrm{~g}$ for $10 \mathrm{~min}$ at $4^{\circ} \mathrm{C}$, the supernatant was discarded; DNA was then spooled out and washed with $1 \mathrm{M}$ ammonium acetate and $100 \%$ ethanol. The cleaned DNA pellet was air dried and dissolved in $100 \mu \mathrm{l}$ of $0.1 \mathrm{X}$ TE buffer (1 mM Tris-HCl, 0.1 mM EDTA, $\mathrm{pH}$ 8.0). After addition of $5 \mu \mathrm{l}$ of RNase $(10 \mathrm{mg} / \mathrm{ml})$, and incubation for $30 \mathrm{~min}$ at $37^{\circ} \mathrm{C}$, the DNA was washed with $1 \mathrm{M}$ ammonium acetate and $100 \%$ ethanol. Then it was centrifuged at $12,000 \mathrm{~g}$ for $30 \mathrm{~min}$ at $4^{\circ} \mathrm{C}$, and the supernatant was discarded; DNA was rinsed twice with $70 \%$ ethanol. The cleaned DNA pellet was air dried and dissolved in $100 \mu$ of $0.1 \mathrm{X}$ TE buffer. The DNA concentration was quantified by DNA fluorimeter and kept at $-80^{\circ} \mathrm{C}$ until use.

\section{RAPD assay}

Thirty-three RAPD primers belonging to Operon Technologies Inc., USA, and three primers from the University of British Columbia were tested for genetic variability detection within $F$. sycomorus species. The amplification reaction was carried out in a $25 \mu \mathrm{l}$ reaction volume containing $1 \mathrm{X}$ PCR buffer, $2 \mathrm{mM} \mathrm{MgCl}, 0.25 \mathrm{mM}$ dNTPs, 25 pmol primer, 1.5 U of Taq DNA polymerase and $50 \mathrm{ng}$ template DNA. PCR amplification was performed in a T-gradient thermal cycler (Bio-Rad; T-Gradient). It was programmed to fulfil 42 cycles after an initial denaturation cycle for $4 \mathrm{~min}$ at $94^{\circ} \mathrm{C}$. Each cycle con- sisted of a denaturation step for $1 \mathrm{~min}$ at $94^{\circ} \mathrm{C}$, an annealing step for $2 \mathrm{~min}$ at $35^{\circ} \mathrm{C}$, and an extension step at $72^{\circ} \mathrm{C}$ for $2 \mathrm{~min}$, followed by an extension cycle for $7 \mathrm{~min}$ at $72^{\circ} \mathrm{C}$ in the final cycle. The PCR products were separated on a $1.5 \%$ ethidium bromide-stained agarose gel (Bio-Rad) in 0.5X TBE buffer. Electrophoresis was performed for $2.5 \mathrm{~h}$ for RAPD at $85 \mathrm{~V}$ and visualised with a UV transilluminator. A $1 \mathrm{~kb}$ DNA ladder standard was used to estimate the molecular weight of the amplification products.

\section{IRAP assay}

For the IRAP marker, 22 (single, or in combination) primers were also examined, as previously described in other species (Guo et al. 2006; Alavi-Kia et al. 2008; Novakova et al. 2009). The amplification reaction was carried out in $25 \mu$ reaction volume containing 1X PCR buffer, $2 \mathrm{mM} \mathrm{MgCl}_{2}$, $0.25 \mathrm{mM}$ dNTPs, 25 pmol primer, $1.5 \mathrm{U}$ of Taq DNA polymerase and $50 \mathrm{ng}$ template DNA. PCR amplification was performed in a T-gradient thermal cycler (Bio-Rad; T-Gradient). It was programmed to fulfil 35 cycles after an initial denaturation cycle for 4 min at $94^{\circ} \mathrm{C}$. Each cycle consisted of a denaturation step for $1 \mathrm{~min}$ at $94^{\circ} \mathrm{C}$, an annealing step for $2 \mathrm{~min}$ at $\mathrm{Tm}$ varied according to each primer examined, and an extension step at $72^{\circ} \mathrm{C}$ for $2 \mathrm{~min}$, followed by extension cycle for $7 \mathrm{~min}$ at $72^{\circ} \mathrm{C}$ in the final cycle. The PCR products were separated on a $2 \%$ ethidium

$\mathrm{T}$ a

Geographical regions, and description of original sites where the $10 \mathrm{~F}$. sycomorus genotypes were collected

\begin{tabular}{|l|c|c|c|c|}
\hline Genotype code & Original site & Accompanied species & Altitude $[\mathrm{m}]$ & Annual rainfall [mm] \\
\hline F. sycomor1 & Lattakia & Eucalyptus ssp and Azadarachtx indica & 4.5 & $650-700$ \\
F. sycomor2 & Lattakia & Azadarachtx indica & 4.5 & $650-700$ \\
F. sycomor3 & Lattakia & None & 6.3 & $650-700$ \\
F. sycomor4 & Lattakia & Cupressus sempervirens & 6.3 & $650-700$ \\
F. sycomor5 & Lattakia & None & 6.3 & $650-700$ \\
F. sycomor6 & Lattakia & Ailanthus altissima & 6.3 & $650-700$ \\
F. sycomor7 & Jableh & Azadarachtx indica & 11.8 & $650-700$ \\
F. sycomor8 & Banyas & None & 10.0 & $700-750$ \\
F. sycomor9 & Banyas & Juglans regia L. & 220.0 & $\sim 850$ \\
F. sycomor10 & Banyas & None & 250.0 & $\sim 850$ \\
\hline
\end{tabular}


bromide-stained agarose gel (Bio-Rad) in 0.5X TBE buffer. Electrophoresis was performed for $1.5 \mathrm{~h}$ at $85 \mathrm{~V}$ and visualised with a UV transilluminator. A $1 \mathrm{~kb}$ DNA ladder standard was used to estimate molecular weight of amplification products.

\section{RAPD and IRAP data analysis}

The presence or absence of each size class was scored as 1 or 0 , respectively. The percent disagreement values (PDV) found were used to generate a matrix via the Unweighted Pair Group Mean Arithmetic average (UPGMA) using Statistica program (Statistica 2003). This matrix was used to calculate genetic similarity (Jaccard 1908). Polymorphic information content (PIC) values were calculated for each RAPD or IRAP primer according to the formula

$$
\mathrm{PIC}=1-\Sigma\left(\mathrm{P}_{\mathrm{ij}}\right)^{2}
$$

where $P_{i j}$ is the frequency of the $i^{\text {th }}$ pattern revealed by the $\mathrm{j}^{\text {th }}$ primer summed across all patterns revealed by the primers (Botestein et al. 1980). The marker index (MI), as a universal metric to represent the amount of information obtained per experiment for a given kind of markers, as reported by Powell et al. (1996), was also calculated for each RAPD and IRAP primer as

$$
\mathrm{MI}=\mathrm{PIC} \times \eta \beta
$$

where PIC is the mean PIC value, $\eta$ the number of bands, and $\beta$ is the proportion of polymorphic.

\section{RESULTS AND DISCUSSION}

PCR amplification produced by RAPD and IRAP primers are listed in Tables 2 and 3 in terms of the percentage of PCR products appearing in the genotypes studied. The RAPD analysis carried out on the 10 genotypes of $F$. sycomorus produced a large number of distinct fragments for each primer. The 36 selected arbitrary primers generated a total of 352 scorable bands, of which $252(71.59 \%)$ were polymorphic, with an average of 9.778 amplicons/ primer (Table 2). OPA18 gave the highest number of fragments (21 amplicons), while OPG11, OPK12 and OPT18 primers revealed the lowest number ( 5 amplicons). Figure 1 shows the RAPD profile for the 10 genotypes yielded by OPK17, UBC132 and OPD20 primers.
As for IRAP analysis, a total of 178 bands were detected, among which 151 bands $(84.83 \%)$ were polymorphic, with the mean of 11.125 bands/primer or primer combination (Table 3 ). The highest number of fragments (17) was obtained with the IRAP-TD$\mathrm{K} 11 \mathrm{~F}$, whereas, the lowest (7) was revealed by (BREP1F+BREP1R, IRAP-TDK1F+IRAP-TDK1R and IRAP-TDK2F+IRAP-TDK2R) primer combinations. PCR amplification products obtained from Sukkula + Nikita, IRAP-TDK11F and Sukkula + LTR6150-BARE1 primer combinations are illustrated in Figure 2.

In this study, two PCR-based systems (RAPD and IRAP) were employed to investigate the genetic diversity among 10 genotypes of $F$. sycomorus grown in Syria.

Our study showed moderate polymorphism level values of $71.59 \%$ (RAPD marker), and high values of $84.83 \%$ (IRAP marker) among the genotypes examined. Other researches, however, reported a good degree of polymorphism in neotropical Ficus (80\%) (Nazareno et al. 2009), in F. carica L. (81.1\%) (De-Masi et al. 2005) using the same marker; in F. carica L. $(97.5 \%$ and $100 \%$ using AFLP and SSR markers, respectively) (Baraket et al. 2011) and $84.96 \%$ and $90.91 \%$ in Arthrocnemum macrostachyum (Saleh 2011) using RAPD and ISSR markers, respectively. Hadia et al. (2008) reported values of $62.4 \%$ and $61.2 \%$ using RAPD and ISSR markers, respectively, in F carica, however, Dalkilic et al. (2011) reported a lower value for the same species (27.9\% using RAPD marker). Singh et al. (2011) also reported a low polymorphism level (P\%) (54.33\% and 56.02\% using, respectively, RAPD and ISSR markers in Morinda spp). Whereas, our results were in agreement with other findings in F. carica (Salhi-Hannaci et al. 2006; Akbulut et al. 2009; Ikegami et al. 2009).

Moreover, Aradhya et al. (2010) used 15 microsatellite loci for genetic diversity in cultivated fig (F. carica L.) to examine the genetic structure and differentiation. Their results revealed weak genetic structure, and they proposed that this was probably due to an inherently narrow genetic base from which the fig was domesticated, combined with historical migration of germplasm, and the outcrossing mode of pollination, all of which have countered human selection in different fig-growing regions of the 
$\mathrm{T}$ a

Selected 36 RAPD primers tested in this study

\begin{tabular}{|c|c|c|c|c|c|c|}
\hline Primer name & Primer Sequence $5^{\circ}$ to $3^{\prime}$ & $\mathrm{Tb}$ & $\mathrm{Pb}$ & $\mathrm{P}[\%]$ & PIC & MI \\
\hline OPA02 & TGCCGAGCTG & 9 & 7 & 77.778 & 0.258 & 1.806 \\
\hline OPA04 & AATCGGGCTG & 10 & 8 & 80.000 & 0.256 & 2.048 \\
\hline OPA 18 & AGGTGACCGT & 21 & 16 & 76.190 & 0.243 & 3.888 \\
\hline OPB01 & GTTTCGCTCC & 10 & 8 & 80.000 & 0.288 & 2.304 \\
\hline OPB04 & GGACTGGAGT & 16 & 10 & 62.500 & 0.225 & 2.250 \\
\hline OPB05 & TGCGCCCTTC & 10 & 9 & 90.000 & 0.220 & 1.980 \\
\hline OPB12 & CCTTGACGCA & 10 & 4 & 40.000 & 0.110 & 0.440 \\
\hline OPB17 & AGGGAACGAG & 10 & 6 & 60.000 & 0.200 & 1.200 \\
\hline OPC02 & GTGAGGCGTC & 10 & 8 & 80.000 & 0.296 & 2.368 \\
\hline OPC07 & GTCCCGACGA & 6 & 5 & 83.333 & 0.250 & 1.250 \\
\hline OPC08 & TGGACCGGTG & 6 & 4 & 66.667 & 0.210 & 0.840 \\
\hline OPC13 & AAGCCTCGTC & 7 & 4 & 57.143 & 0.169 & 0.676 \\
\hline OPC15 & GACGGATCAG & 8 & 6 & 75.000 & 0.310 & 1.860 \\
\hline OPD08 & GTGTGCCCCA & 9 & 3 & 33.333 & 0.060 & 0.180 \\
\hline OPD20 & GGTCTACACC & 14 & 10 & 71.429 & 0.190 & 1.900 \\
\hline OPE04 & GTGACATGCC & 8 & 6 & 75.000 & 0.190 & 1.140 \\
\hline OPE07 & AGATGCAGCC & 11 & 9 & 81.818 & 0.347 & 3.123 \\
\hline OPE15 & ACGCACAACC & 9 & 7 & 77.778 & 0.260 & 1.820 \\
\hline OPE18 & GGACTGCAGA & 11 & 8 & 72.727 & 0.230 & 1.840 \\
\hline OPG11 & TGCCCGTCGT & 5 & 2 & 40.000 & 0.168 & 0.336 \\
\hline OPJ01 & CCCGGCATAA & 12 & 11 & 91.667 & 0.202 & 2.222 \\
\hline OPJ07 & CCTCTCGACA & 11 & 10 & 90.909 & 0.330 & 3.300 \\
\hline OPK08 & GAACACTGGG & 10 & 9 & 90.000 & 0.286 & 2.574 \\
\hline OPK12 & TGGCCCTCAC & 5 & 3 & 60.000 & 0.136 & 0.408 \\
\hline OPK13 & GGTTGTACCC & 8 & 4 & 50.000 & 0.190 & 0.760 \\
\hline OPK17 & CCCAGCTGTG & 13 & 10 & 76.923 & 0.190 & 1.900 \\
\hline OPQ01 & GGGACGATGG & 10 & 6 & 60.000 & 0.138 & 0.828 \\
\hline OPQ18 & AGGCTGGGTG & 7 & 4 & 57.143 & 0.171 & 0.684 \\
\hline OPR12 & ACAGGTGCGT & 10 & 3 & 30.000 & 0.106 & 0.318 \\
\hline OPT18 & GATGCCAGAC & 5 & 2 & 40.000 & 0.072 & 0.144 \\
\hline OPV03 & СTCCCTGCAA & 12 & 11 & 91.667 & 0.313 & 3.443 \\
\hline OPW17 & GTCCTGGGTT & 10 & 9 & 90.000 & 0.236 & 2.124 \\
\hline OPY10 & CAAACGTGGG & 10 & 8 & 80.000 & 0.226 & 1.808 \\
\hline UBC132 & AGGGATCTCC & 10 & 6 & 60.000 & 0.186 & 1.116 \\
\hline UBC159 & GAGCCCGTAG & 12 & 10 & 83.333 & 0.248 & 2.480 \\
\hline $\mathrm{UBC} 702$ & GGGAGAAGGG & 7 & 6 & 85.714 & 0.217 & 1.302 \\
\hline Total & & 352 & 252 & - & - & - \\
\hline Mean & & 9.778 & 7 & 69.990 & 0.215 & 1.629 \\
\hline
\end{tabular}

$\mathrm{Tb}$ - Total bands; $\mathrm{Pb}$ - Polymorphic bands; P [\%] - Polymorphic \%; PIC - Polymorphic information content; MI - Marker index 
$\mathrm{T}$ a

Selected 22 IRAP primers tested in this study

\begin{tabular}{|c|c|c|c|c|c|c|c|}
\hline Primer name & Primer Sequence 5' to 3' & $\mathrm{Ta}\left[{ }^{\circ} \mathrm{C}\right]$ & $\mathrm{Tb}$ & $\mathrm{Pb}$ & $\mathrm{P}[\%]$ & PIC & MI \\
\hline BREP1 F & AAGTATTCGGTGTCCAAAATC & 45 & 7 & 5 & 71.429 & 0.269 & 1.345 \\
\hline BREP1 R & ACTCCCTGTTGAAAATTCTGA & & & & & & \\
\hline IRAP-TDK1F & TCAATCGGACTTGTTCAAAACCCCA & 45 & 7 & 3 & 42.857 & 0.197 & 0.591 \\
\hline IRAP-TDK1R & TACAGACCAAATGCTCACCATCACT & & & & & & \\
\hline IRAP-TDK2F & GAAGTTAGTGGGAGCAAAAGATGT & 45 & 7 & 6 & 85.714 & 0.254 & 1.524 \\
\hline IRAP-TDK2R & TACCAATGTCGGGAGGCTTGTGTCA & & & & & & \\
\hline BREP F & TTCAAGATTTCTGACCTTTCG & 45 & 10 & 10 & 100.000 & 0.330 & 3.300 \\
\hline BREP R & CCAGTGGCACATCAAAACAAAA & & & & & & \\
\hline IRAP-TDK10F & CTTTGTGATAGAACTTGGGTTTGCT & 45 & 12 & 10 & 83.333 & 0.305 & 3.05 \\
\hline IRAP-TDK11F & AGGTATGGTTTCAAGATGATGGATG & 45 & 17 & 15 & 88.235 & 0.282 & 4.23 \\
\hline IRAP-TDK12F & ATACAACAGACTCAATGCCGACCCT & 45 & 8 & 6 & 75.000 & 0.240 & 1.440 \\
\hline IRAP-TDK12R & ACCTGCCAACCAACTTCTTTTCCTC & & & & & & \\
\hline IRAP-TDK13F & TCCTGATGGGAACTTCGTTGCTCGT & 45 & 12 & 11 & 91.667 & 0.295 & 3.245 \\
\hline IRAP-TDK13R & CCTGACACCTCAAAACCTTCTGGCT & & & & & & \\
\hline Sukkula & GATAGGGTCGCATCTGGGCGTGAC & 45 & 14 & 13 & 92.857 & 0.339 & 4.407 \\
\hline 5'LT R2-BARE-1 & ATCATTCTCTAGGGCATAATTC & & & & & & \\
\hline Sukkula & GATAGGGTCGCATCTGGGCGTGAC & 45 & 13 & 11 & 84.615 & 0.342 & 3.762 \\
\hline LT R6150-BARE-1 & CTGGTTCGGCCATGTCTATGTATCACACATGTA & & & & & & \\
\hline Sukkula & GATAGGGTCGCATCTGGGCGTGAC & 45 & 15 & 14 & 93.333 & 0.387 & 5.418 \\
\hline Nikita & CGCATTGTTCAAGCCTAAACC & & & & & & \\
\hline 3'LT R-BARE-1 & TGTTCATGCGACGTTCAACA & 44 & 12 & 11 & 91.667 & 0.337 & 3.707 \\
\hline 5'LT R2-BARE-1 & ATCATTCTCTAGGGCATAATTC & & & & & & \\
\hline 3'LT R-BARE-1 & TGTTCATGCGACGTTCAACA & 44 & 11 & 10 & 90.909 & 0.362 & 3.620 \\
\hline Nikita & CGCATTGTTCAAGCCTAAACC & & & & & & \\
\hline 3'LT R-BARE-1 & TGTTCATGCGACGTTCAACA & 44 & 13 & 8 & 61.539 & 0.223 & 1.784 \\
\hline P-Tst-6 & ACTAAATCTGCCTACTCATTCAACACTC & 55 & 9 & 8 & 88.889 & 0.327 & 2.616 \\
\hline P-Tst-1 & ATGACTAAATCTGCCTACTCATTCAACA & 45 & 11 & 10 & 90.909 & 0.302 & 3.020 \\
\hline P-Tst-3 & ACTAAAAATCTGCCTACTCATTCAACACTC & & & & & & \\
\hline \multicolumn{3}{|l|}{ Total } & 178 & 151 & - & - & - \\
\hline \multicolumn{3}{|l|}{ Mean } & 11.125 & 9.438 & 83.309 & 0.299 & 2.941 \\
\hline
\end{tabular}

Ta $\left[{ }^{\circ} \mathrm{C}\right]$ - Annealing temperature; Tb - Total bands; $\mathrm{Pb}$ - Polymorphic bands; $\mathrm{P}[\%]$ - Polymorphic \%; PIC - Polymorphic information content; MI - Marker index 
world. Moreover, in Weiblen's (2000) investigation, separated and combined phylogenetic analyses of ITS and morphological characters indicate that monoecious Sycomorus is monophyletic and nested in a clade of functionally dioecious Ficus.

In the present investigation, the PIC value estimated with RAPD assay ranged from 0.060 to 0.347 with an average of 0.215 , whereas, this index varied between 0.197 and 0.387 with an average of 0.299 using an IRAP marker. Dalkilic et al. (2011), obtained values that ranged from 0.16 to 0.50 in male fig (Ficus carica caprificus L.) genotypes using an RAPD marker, whereas, this value was recorded to be 0.79 and 0.94 in fig (F. carica L.) using AFLP and SSR markers, respectively (Baraket et al. 2011).

For determining the overall usefulness of a given marker system, the MI was calculated for both the marker systems examined. IRAP markers showed the highest MI (2.941; Table 3), which is higher than the estimated value for the RAPD (1.629; Table 2). This analysis highlights the distinctive nature of the IRAP assay. Indeed, the MI, considered to be an overall measurement of the efficiency to detect polymorphism, was higher (2.941) for IRAP than (1.629) for RAPD marker systems (Tables 2 and $3)$. According to the formula used, the high-value MI calculated for the IRAP assay, makes the IRAP marker system suitable for estimating the level of genetic diversity in F. sycomorus genotypes compared with the RAPD system. Consequently, IRAP fingerprinting was more efficient than the RAPD assay. The present results were in accordance with the observation by Biswas et al. (2009) in citrus, while, this value was 45.2 and 0.94 for AFLP and

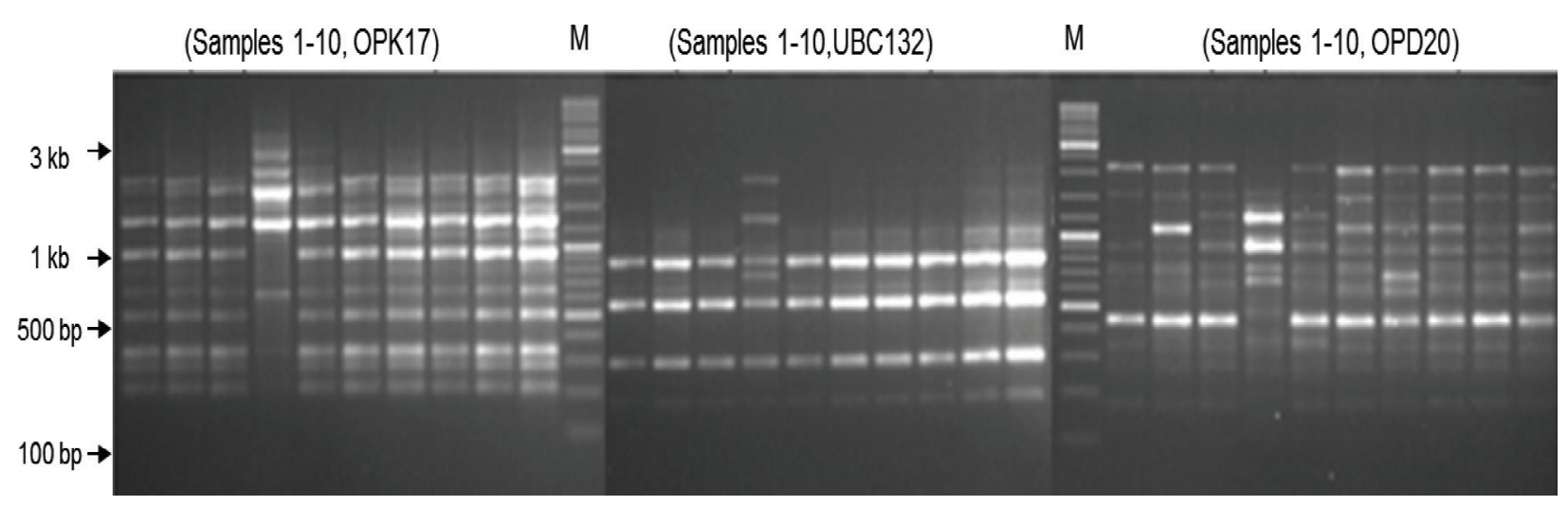

Figure 1. Polymorphism resultant from the use of OPK17, UBC132 and OPD20 RAPD primers for F. sycomorus genotypes 1, 2, 3 and 10, Lane M, DNA marker $1 \mathrm{~kb}$

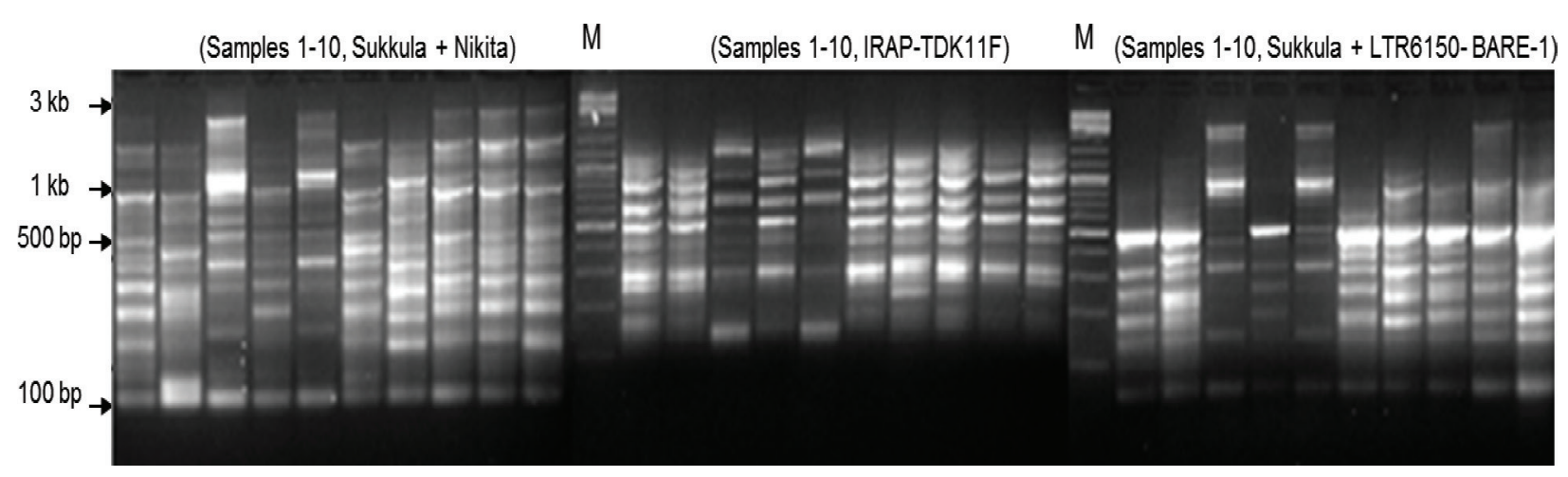

Figure 2. Polymorphism resultant from the use of Sukkula + Nikita, IRAP-TDK11F and Sukkula + LTR6150BARE-1 IRAP primer combinations for F. sycomorus genotypes 1, 2, 3 and 10, Lane M, DNA marker $1 \mathrm{~kb}$ 
SSR markers, respectively, in F. carica L. (Baraket et al. 2011).

Genetic similarity estimated among genotypes was scaled between 0.401 and 0.897 , with an average of 0.705 in the case of RAPD, and between 0.205 and 0.976 with an average of 0.623 in the case of IRAP markers. While, this value was higher than that previously reported using the same technique in $F$. carica L., it was estimated to be $(0.21-0.62)$ with an average of 0.468 in the Akbulut et al. (2009) investigation with RAPD markers, ranging between 0.04 and 0.59 , with an average of 0.32 (for AFLP) and between $0.017-0.546$ with an average of 0.281 (for SSR) in the Baraket et al. (2011) study, where-

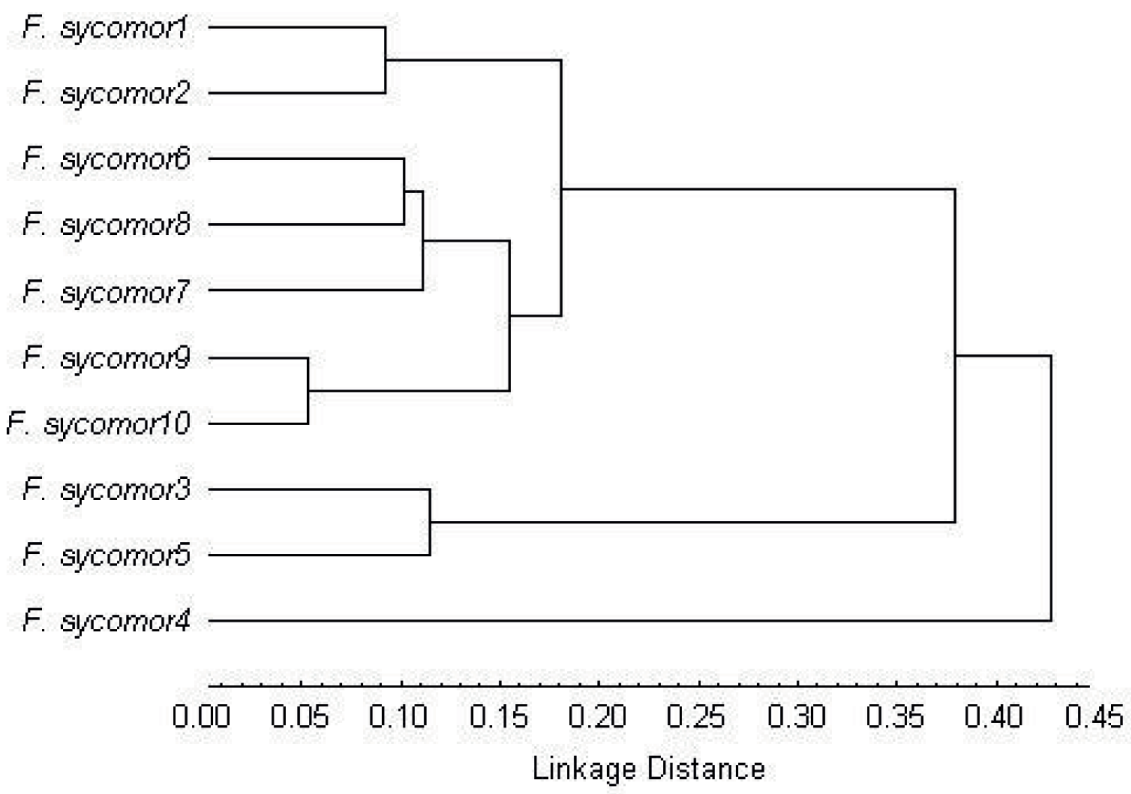

Figure 3. UPGMA cluster analysis-based on the percent disagreement value for RAPD and IRAP data combination showing genetic relationship among the 10 genotypes of $F$. sycomorus L. species

$\mathrm{T}$ a

Percent disagreement values (PDV) produced by RAPD and IRAP (single or in combination) data combination using the UPGMA routine in statistical program

\begin{tabular}{|c|c|c|c|c|c|c|c|c|c|c|}
\hline Genotype & F. sycomor I & F. sycomor 2 & F. sycomor 3 & F. sycomor 4 & F. sycomor 5 & F. sycomor 6 & F. sycomor 7 & F. sycomor 8 & F. sycomor 9 & F. sycomor10 \\
\hline F. sycomor I & 0 & & & & & & & & & \\
\hline F. sycomor 2 & 0.09 & 0 & & & & & & & & \\
\hline F. sycomor 3 & 0.34 & 0.37 & 0 & & & & & & & \\
\hline F. sycomor 4 & 0.40 & 0.42 & 0.38 & 0 & & & & & & \\
\hline F. sycomor 5 & 0.36 & 0.36 & 0.12 & 0.38 & 0 & & & & & \\
\hline F. sycomor 6 & 0.17 & 0.15 & 0.39 & 0.45 & 0.36 & 0 & & & & \\
\hline F. sycomor 7 & 0.21 & 0.19 & 0.41 & 0.44 & 0.37 & 0.11 & 0 & & & \\
\hline F. sycomor 8 & 0.19 & 0.16 & 0.39 & 0.46 & 0.37 & 0.10 & 0.12 & 0 & & \\
\hline F. sycomor 9 & 0.17 & 0.16 & 0.40 & 0.45 & 0.38 & 0.15 & 0.15 & 0.11 & 0 & \\
\hline F. sycomor 10 & 0.20 & 0.19 & 0.41 & 0.46 & 0.40 & 0.18 & 0.19 & 0.14 & 0.05 & 0 \\
\hline
\end{tabular}


Jaccard's similarity matrix produced by RAPD and IRAP (single or combination) data combination for the $10 \mathrm{~F}$. sycomorus tested genotypes

\begin{tabular}{|c|c|c|c|c|c|c|c|c|c|c|}
\hline Genotype & F. sycomor 1 & F. sycomor 2 & F. sycomor 3 & F. sycomor 4 & F. sycomor 5 & F. sycomor 6 & F. sycomor 7 & F. sycomor 8 & F. sycomor 9 & F. sycomor 10 \\
\hline F. sycomorl & 1 & & & & & & & & & \\
\hline F. sycomor 2 & 0.857 & 1 & & & & & & & & \\
\hline F. sycomor 3 & 0.529 & 0.506 & 1 & & & & & & & \\
\hline F. sycomor 4 & 0.485 & 0.477 & 0.473 & 1 & & & & & & \\
\hline F. sycomor 5 & 0.508 & 0.516 & 0.798 & 0.483 & 1 & & & & & \\
\hline F. sycomor 6 & 0.747 & 0.789 & 0.481 & 0.447 & 0.518 & 1 & & & & \\
\hline F. sycomor 7 & 0.704 & 0.740 & 0.471 & 0.465 & 0.517 & 0.843 & 1 & & & \\
\hline F. sycomor 8 & 0.734 & 0.770 & 0.495 & 0.454 & 0.516 & 0.850 & 0.836 & 1 & & \\
\hline F. sycomor 9 & 0.755 & 0.781 & 0.492 & 0.464 & 0.512 & 0.783 & 0.790 & 0.840 & 1 & \\
\hline F. sycomor 10 & 0.722 & 0.739 & 0.485 & 0.461 & 0.501 & 0.759 & 0.753 & 0.805 & 0.924 & 1 \\
\hline
\end{tabular}

as, it was varied between 0 and 0.78 with an average of 0.39 (Salhi-Hannaci et al. 2006), between 0.20 and 0.85 with an average of 0.51 (Cerqueira-Silva et al. 2010) in Passiflora cincinnata, between 0.181 and 0.562 with an average of 0.543 using an RAPD marker in Arthrocnemum macrostachyum (Saleh 2011), and in the study reported by Ikegami et al. (2009) on F. carica L., the average was 0.717 .

Combined RAPD and IRAP data produced genetic distances ranging from 0.05 to 0.46 with a mean of 0.28 (Table 4), and the resultant dendrogram (Figure 3) demonstrated that the $10 \mathrm{~F}$. sycomorus genotypes phylogenetics fell into two main groups. The first cluster consisted of $F$. sycomor 4 genotype that formed a distinct cluster with a PDV estimated value higher than 0.38 with other tested genotypes, especially with $F$. sycomor 8 and $F$. sycomor 4 , and with $F$. sycomor 10 and $F$. sycomor $4(\mathrm{PDV}=0.46)$, whereas, the second cluster included the remaining genotypes. Subsequently, the last cluster was further divided into four subclusters containing the remaining tested genotypes. The first subcluster involved genotypes $F$. sycomor 1 and 2 that were closely related at PDV $=0.09$ (similarity 0.857 , Table 5). While, the second subcluster included F. sycomor 6 and 8 , that were closely related at $\mathrm{PDV}=0.1$ (similarity 0.850 , Table 5). This subcluster was closed to $F$. sycomor 7 at PDV $=0.11$ (similarity 0.843 , Table 5 ) and with $F$. sycomor8 at $\mathrm{PDV}=0.12$ (similarity 0.836 , Table 5), whereas, the third subcluster consisted of
F. sycomor 9 and 10 that were the most related genotypes with a PDV $=0.05$ ) similarity 0.924 , Table 5). The fourth and last subcluster involved F. sycomor 3 and $F$. sycomor 5 that were also closely related at PDV $=0.12$ (similarity 0.798 , Table 5 ).

Our results demonstrated that the genotypes studied are clustered independently from their geographical origin. Taking into account that F. sycomorus genotypes aggregated together in the same cluster, this indicated a possible common origin of these genotypes.

This is in agreement with the monoecious origin of Ficus that has evolved into two gynodioecious forms as suggested by Machado et al. (2001). It is important to note that similar data have been reported in Tunisian fig using RAPD markers (Salhi Hannachi et al. 2006).

\section{CONCLUSION}

Overall, this study clearly demonstrates a relatively high diversity among $F$. sycomorus genotypes found in the coastal regions of Syria. Moreover, the two techniques applied may provide useful information on polymorphism levels as well as diversity in F. sycomorus L. species, but the IRAP marker differentiates accessions much better than the RAPD marker system. Consequently, the IRAP technique could be performed as a high-accuracy approach 
compared with the RAPD tool. Moreover, F. sycomor4 genotype showed the highest dissimilarity compared to the other genotypes studied in this investigation. According to the dendrogram based on a combination of RAPD and IRAP data, it could be suggested, that $F$. sycomor 4 genotype belongs to a subspecies that is different from that of the remaining genotypes.

In this investigation, it was not easy to predict the exact number of subspecies studied herein, especially since the exact number of $F$. sycomorus subspecies found in Syria is not known. Based upon the previous observation, and according to the position of genotypes presented by UPGMA cluster analysis, it may be postulated, however, that there are three subspecies present among the 10 samples tested. The first subspecies involved F. sycomorus 3 and $F$. sycomorus 5 genotypes, the second involved $F$. sycomorus 4 which was being suggested as presenting a distinct subspecies from the other genotypes tested, whereas, the third involved the remaining tested genotypes. Based upon the results obtained herein, it is satisfying to confirm the previous data using more potential techniques such as, for example, SSR and universal cytoplasmic molecular markers. Thereby, further analyses are required to confirm the number of subspecies to which F. sycomorus trees growing in Syria belong.

Acknowledgements. The author would like to thank Prof. Othman I, Director General of AECS and Prof. MirAli N, Head of Molecular Biology and Biotechnology Department for their support, and also to the Plant Biotechnology group for technical assistance.

\section{REFERENCES}

AKBULUT, M. - ERCISLI, S. - KARLIDAG, H. 2009. APD-based study of genetic variation and relationships among wild fig genotypes in Turkey. In Genetics and Molecular Research, vol. 8, no. 3, pp. 1109-1115. DOI: 10.4238/vo19-4gmr957.

ALAVI-KIA, S.S. - MOHAMMADI, S.A. - AHARIZAD, S. - MOGHADDAM, M. 2008. Analysis of genetic diversity and phylogenetic relationships in Crocus genus of Iran using inter-retrotransposon amplified polymorphism. In Biotechnology and Biotechnological Equipment, vol. 22, no. 3, pp. 795-800.
AL MALKI, A.A.H.S. - ELMEER K.M.S. 2010. Influence of auxin and cytokinine on in vitro multiplication of Ficus anastasia. In African Journal of Biotechnology, vol. 9, no. 5, pp. 635-639. DOI: 10.5897/ AJB 09.1168.

ARADHYA, M.K. - STOVER, E.D. - VELASCO, D. - KOEHMSTEDT, A. 2010. Genetic structure and differentiation in cultivated fig (Ficus carica L.). In Genetica, vol. 138, pp. 681-694. DOI: 10.1007/ s10709-010-9442-3.

BARAKET, G. - CHATTI, K. - SADDOUD, O. - BEN ABDELKARIM, A. - MARS, M. - TRIFI, M. - SAHI HANNACHI, A. 2011. Comparative assessment of SSR and AFLP markers for evaluation of genetic diversity and conservation of fig, Ficus carica L., genetic resources in Tunisia. In Plant Molecular Biology Reporter, vol. 29, pp. 171-184. DOI: 10.1007/ s11105-010-0217-x.

BARKOUDAH, Y. - DARWISH, A.I. - ABI ANTOUN, M. 2000. Biological diversity, National repot. Biodiversity strategy and action plant and report to conference of the parties NBSAP project SY/97/G31. UNDP - GEF.

BISWAS, M.K. - XU, O. - DENG, X. 2009. Utility of RAPD, ISSR, IRAP and REMAP markers for genetic analysis of Citrus spp. In Scientia Horticulturae, vol. 124, pp. 245-261.

BOTSTEIN, D. - WHITE, R.L. - SKOLINCK, M. - DAVIS, R.W. 1980. Contraction of a genetic linkage map in man using restriction fragment length polymorphisms. In American Journal of Human Genetics, vol. 32, pp. 314-331.

CERQUEIRA-SILVA, C.B.M. - CONCEICAO, L.D.H.C.S. - SANTOS, E.S.L. - CARDOSO-SILVA, C.B. - PEREIRA, A.S. - OLIVEIRA, A.C. - CORREA R.X. 2010. Genetic variability in wild genotypes of Passiflora cincinnata based on RAPD markers. In Genetics and Molecular Research, vol. 9, no. 4, pp. 2421-2428. DOI: $10.4238 /$ vo19-4gmr981.

DALKILIC, Z. - MESTAV, H.O. - GUNVER-DALKILIC, G. - KOCATA, H. 2011. Genetic diversity of male fig (Ficus carica caprificus L.) genotypes with random amplified polymorphic DNA (RAPD) markers. In African Journal of Biotechnology, vol. 10, no. 4, pp. 519-526. DOI: 10.5897/AJB10.995.

DE MASI, L. - CASTADO, D. - GALANO, G. - MINASI, P. - LARATTA, B. 2005. Genotyping of fig ( $F i$ cus carica L.) via RAPD markers. In Journal of the Science of Food and Agriculture, vol. 85, pp. 22352242. DOI: $10.1002 /$ jsfa.2247.

DOYLE, J.J. - DOYLE, J.L. 1987. A rapid DNA isolation procedure for small quantities of fresh leaf tissue. In Phytochemical Bulletin, vol. 19, 1987, pp. 11-15.

GUO, D. - Zhang, H. - Luo, Z. 2006. Genetic relationships of Diospyros kaki Thunb. and related species revealed by IRAP and REMAP analysis. In Plant Science, vol. 170, no. 3, pp. 528-533. DOI: $10.1016 / \mathrm{j}$. plantsci.2005.10.006.

HADIA, H.A. - EL-MOKADEM, H.E. - EL-TAYEB, H.F. 2008. Phylogenetic relationship of four Ficus species using random amplified polymorphic DNA 
(RAPD) and inter-simple sequence repeat (ISSR) markers. In Journal of Applied Sciences Research, vol. 4 , no. 5, pp. 507-514.

IKEGAMI, H. - NOGATA, H. - HIRASHIMA, K. AWAMURA, M. - NAKAHARA, T. 2009. Analysis of genetic diversity among European and Asian fig varieties (Ficus carica L.) using ISSR, RAPD, and SSR markers. In Genetic Resources and Crop Evolution, vol. 56, pp. 201-209. DOI: 10.1007/s10722008-9355-5.

JACCARD, P. 1908. Nouvelles recherches sur la distribution flora. In Bulletin de la Societé Vaudoise des Sciences Naturelles, vol. 44, pp. 223-270.

MACHADO, C.A. - JOUSSELIN, E. - KJELLBERG, F. COMPTON, S.G. - HERRE, E.A. 2001. Phylogenetic relationships, historical biogeography and character evolution of fig pollinating wasps. In Proceedings of the Royal Society, London Biological Science, vol. 268, pp. 7-10.

MOUTERDE, P. 1966. Nouvelle flore du Liban et de la Syrie. Vol 1 (Texte), Beyrouth-Liban, pp. 371-372.

NAIR, A.S. - TEO, C.H. - SCHWARZACHER, T. - HARRISON, P.H. 2005. Genome classification of banana cultivars from South India using IRAP markers. In Euphytica, vol. 144, no. 3, pp. 285-290. DOI: 10.1007/s10681-005-7321-2.

NAZARENO, A.G. - PEREIRA, R.A.S. - FERAS, J.M. MESTRINER, M.A. - ALZATE-MARIN, A.L. 2009. Transferability and characterization of microsatellite markers in two Neotropical Ficus species. In Genetics and Molecular Biology, vol. 32, no. 3, pp. 568-571. DOI: org/10.1590/S1415-47572009005000056.

NOVÁKOVÁ, A. - ŠIMÁČKOVÁ, K. - BÁRTA, J. ČURN, V. 2009. Potato variety identification by molecular markers based on retrotransposon analyses. In Czech Journal of Genetics and Plant Breeding, vol. 45 , no. 1 , pp. 1-10.

POWELL, W. - MORGANTE, M. - ANDRE, C. HANAFEY, M. - VOGEL, J. - TINGEY, S. - RAFALSKY, A. 1996. The comparison of RFLP, RAPD, AFLP and SSR (microsatellite) markers for germplasm analysis. In Molecular Breeding, vol. 2, no. 3, pp. 225-238. DOI: 10.1007/BF00564200.

SAEIDI, H. - RAHIMINEJAD, M.R. - HESLOP-HARRISON, J.S. 2008. Retroelement insertional poly- morphisms, diversity and phylogeography within diploid, D-genome Aegilops tauschii (Triticeae, Poaceae) Sub-taxa in Iran. In Annals of Botany, vol. 101, no. 6, pp. 855-861. DOI: $10.1093 / \mathrm{aob} / \mathrm{mcn} 042$.

SALEH, B. 2011. Efficiency of RAPD and ISSR markers in assessing genetic variation in Arthrocnemum macrostachyum (Chenopodiaceae). In Brazilian Archives of Biology and Biotechnology, vol. 54, no. 5, pp. 859-866.

SALHI-HANNACHI, A. - CHATTI, K. - SADDOUD, O. - MARS, M. - RHOUMA, A. - MARRAKCHI, M. - TRIFI, M. 2006. Genetic diversity of different Tunisian fig (Ficus carica L.) collections revealed by RAPD fingerprints. In Hereditas, vol. 143, pp. 15-22.

SINGH, D.R. - SRIVASTAVA, A.K. - SRIVASTAVA, A. - SRIVASTAVA, R.C. 2011. Genetic diversity among three Morinda species using RAPD and ISSR markers. In Indian Journal of Biotechnology, vol. 10, no. 3, pp. 285-293.

SMÝKAL, P. - BAČOVÁ-KERTESZOVÁ, N. - KALENDAR, R. - CORANDER, J. - SCHULMAN, A.H. PAVELEK, M. 2011. Genetic diversity of cultivated flax (Linum usitatissimum L.) germplasm assessed by retrotransposon-based markers. In Theoretical and Applied Genetics, vol. 122, no. 7, pp. 1385-1397. DOI: $10.1007 / \mathrm{s} 00122-011-1539-2$.

STATSOFT, 2003. Statistica (Data analysis software system), version 6. Statsoft Inc. www.statsoft.com.

WEIBLEN, G.D. 2000. Phylogenetic relationships of functionally dioecious Ficus (Moraceae) based on ribosomal DNA sequence and morphology. In American Journal of Botany, vol. 87, no. 9, pp. 1342-1357. DOI: $10.2307 / 2656726$.

WILLIAMS, J.G.K. - KUBELIK, A.R. - LIVAK, K.J. - RAFALSKI, J.A. - TINGEY, S.V. 1990. DNA Polymorphisms amplified by arbitrary primers are useful as genetic markers. In Nucleic Acids Research, vol. 18, no. 22, pp. 6531-6535.

ZOHARY, M. 1962. Plant life of Palestine. The Ronald Press Co. : New York-USA, 262 pp.

ZOHARY, M. 1973. Geobotanical foundation of Middle East. Gustav Fischer Verlag: Stuttgart-Germany, 739 pp.

Received: March 13 $3^{\text {th }}, 2013$ 